Kamil WĘGLARZ1 ${ }^{1}$, Marcin SIDZINA ${ }^{2}$

Opiekun naukowy: Tomasz KNEFEL ${ }^{3}$

DOI: https://doi.org/10.53052/9788366249837.27

\title{
ProjeKT HAMOWNi SILNIKOWEJ do CELóW DYDAKTYCZNYCH
}

\begin{abstract}
Streszczenie: Aby umożliwić kształcenie studentów i uczniów techników z dziedziny budowy i działania silników trakcyjnych stosowanych do napędu pojazdów samochodowych konieczne jest zaznajomienie ich z podstawowymi parametrami pracy silnika i metodami badawczymi pozwalającymi na ich zmierzenie. Stosuje się w tym celu m.in. hamownie silnikowe stacjonarne. Niestety są one urządzeniami kosztownymi, wymagającymi dużych pomieszczeń i specjalistycznej obsługi. W celu zmniejszenia nakładów koniecznych na szkolenie opracowano projekt hamowni silnikowej bazującej na agregacie prądotwórczym.
\end{abstract}

Słowa kluczowe: hamownia silnikowa, agregat prądotwórczy, patent, szkolenie

\section{ENGINE TEST BENCH DESIGN FOR TEACHING PURPOSE}

Summary: In order to train students and technical apprentices in the field of construction and operation of traction motors used to drive motor vehicles, it is necessary to familiarize them with the basic parameters of engine operation and research methods allowing for their measurement. For this purpose, it is used, inter alia, stationary engine dynamometers. Unfortunately, they are expensive devices that require large rooms and specialist service. In order to reduce the expenses necessary for training, a project of engine dynamometer based on a generator set was developed.

Keywords: engine test bench, power generator, patent, training

\section{Wprowadzenie}

Jednym z elementów kształcenia przyszłej kadry inżynierskiej z zakresu budowy i eksploatacji silników spalinowych bądź elektrycznych jest zaznajomienie z procesem testowania silnika na hamowni. Tego rodzaju test pozwala wyznaczyć podstawowe

\footnotetext{
${ }^{1}$ mgr inż., Wydział Budowy Maszyn i Informatyki, Akademia Techniczno-Humanistyczna w Bielsku-Białej, e-mail: kweglarz@2com.pl

${ }^{2}$ mgr inż., Wydział Mechaniki i Budowy Maszyn, Akademia Techniczno-Humanistyczna w Bielsku-Białej, e-mail: msidzina@gmail.com

${ }^{3}$ dr hab. inż. Prof. ATH, Wydział Budowy Maszyn i Informatyki, Akademia TechnicznoHumanistyczna w Bielsku-Białej, e-mail: knefel@ath.bielsko.pl
} 
charakterystyki pracy silnika takie jak: przebieg krzywej maksymalnego momentu obrotowego, mocy, godzinowego zużycia paliwa oraz zależności między nimi. Możliwe jest także wyznaczenie charakterystyk przy obciążeniach częściowych oraz charakterystyki uniwersalnej, co pozwala na dalsze analizy i przeprowadzenie całego procesu doboru silnika do konkretnego zastosowania (napędu) wraz z obliczeniem przełożeń, czy wyznaczeniem charakterystyk trakcyjnych pojazdu.

Niestety budowa stacjonarnej hamowni silnikowej jest kosztowna i niewiele, placówek edukacyjnych jest w nią wyposażonych. Kosztowna jest zarówno zabudowa wymagająca wydzielenia niezbędnych pomieszczeń o specjalnym przeznaczeniu, zakup oprzyrządowania jak i późniejsza eksploatacja.

Celowym zatem jest opracowanie hamowni silnikowej, która pozwoli zobrazować budowę i działanie tejże, bez konieczności ponoszenia znacznych nakładów finansowych na budowę i obsługę.

\section{Wstęp}

Jedną z metod pomiarowych wykorzystywanych do oceny mocy jednostek napędowych pojazdów jest tzw. metoda obciążeniowa. Metoda obciążeniowa umożliwia bardzo precyzyjny pomiar momentu obrotowego silnika przy stałej prędkości obrotowej, który dokonywany jest poprzez pomiar momentu reakcyjnego na obudowie hamulca. Moc obliczana jest w dalszej kolejności jako iloczyn momentu i szybkości kątowej.

Dla założonej z góry szybkości obrotowej silnika zmieniane są nastawy regulacyjne silnika i dobierane maksymalne obciążenie (hamulcem), przy którym wartość realizowanej prędkości obrotowej jest stabilna. Pomiar trwa kilka sekund a następnie procedura jest powtarzana dla kolejnej wybranej wartości prędkości obrotowej. Charakterystyka składa się z kilkunastu lub kilkudziesięciu punktów pomiarowych w zależności od potrzeb. Pomiar nie musi odbywać się przy maksymalnym otwarciu przepustnicy, co umożliwia np. sporządzanie charakterystyk częściowych.

Metoda ta jest bardzo przydatna przy precyzyjnym regulowaniu silnika ponieważ można właściwie dobrać obciążenie i czas pomiaru w poszczególnych punktach, co jest istotne z punktu widzenia konstrukcji danego silnika. [3]

Opisaną powyżej metodę wykorzystuje zaprojektowana i zgłoszona w Urzędzie Patentowym RP hamownia do celów dydaktycznych. Pozwala ona na przystępne zaprezentowanie opisanej wyżej metody pomiaru w celu lepszego jej zrozumienia.

\section{Założenia wstępne}

Przedmiotem rozważań jest prosta hamownia silnikowa, która może być wykorzystywana do celów dydaktycznych. Charakteryzuje się tym, że do jej budowy wykorzystuje się komponenty agregatu prądotwórczego o mocy od 2 do $5 \mathrm{~kW}$. Prezentowany tutaj projekt oparto na agregacie produkcji firmy Honda, model ECT7000P (rys. 1).

Celem głównym projektu było zminimalizowanie niezbędnych do budowy elementów dodatkowych. Ponadto wykorzystane do budowy elementy dodatkowe są powszechnie dostępne i tanie. Przedstawiona w niniejszej publikacji hamownia do 
pomiaru momentu obrotowego silnika może wykorzystywać zarówno wagę, jak i przetwornik siły. Nie wymaga przy tym żadnego systemu komputerowego do obsługi, co dodatkowo obniża koszty zarówno budowy jak i przyszłej obsługi.

Rozwiązanie, w ogólnej koncepcji, polega na wykorzystaniu komponentów agregatu prądotwórczego dowolnego producenta i jego modyfikacji w taki sposób, aby możliwe było:

1) zadawanie dowolnej prędkości obrotowej silnika spalinowego i jej stabilizacja przy wykorzystaniu wbudowanego w generator mechanicznego regulatora prędkości obrotowej,

2) rozdzielenie mechaniczne korpusu silnika i obudowy prądnicy tak, aby umożliwić pomiar momentu obrotowego generowanego przez silnik spalinowy,

3) zastosowanie wahliwej i łożyskowanej podstawy prądnicy celem pomiaru momentu obrotowego generowanego przez silnik spalinowy,

4) zastosowanie wagi wiszącej (mechanicznej bądź elektronicznej) w celu odczytu aktualnej wartości momentu obrotowego silnika.

Wykorzystanie możliwie prostych i tanich komponentów zwiększa walory dydaktyczne projektu, bowiem umożliwia zrozumienie procesów zachodzących podczas pracy silnika i zasady działania samej hamowni.

\section{Budowa}

Rysunek 1 przedstawia agregat prądotwórczy dowolnego producenta z wyszczególnieniem poszczególnych układów z zastrzeżeniem, że wykorzystany agregat musi być wyposażony we wszystkie z wymienionych elementów.

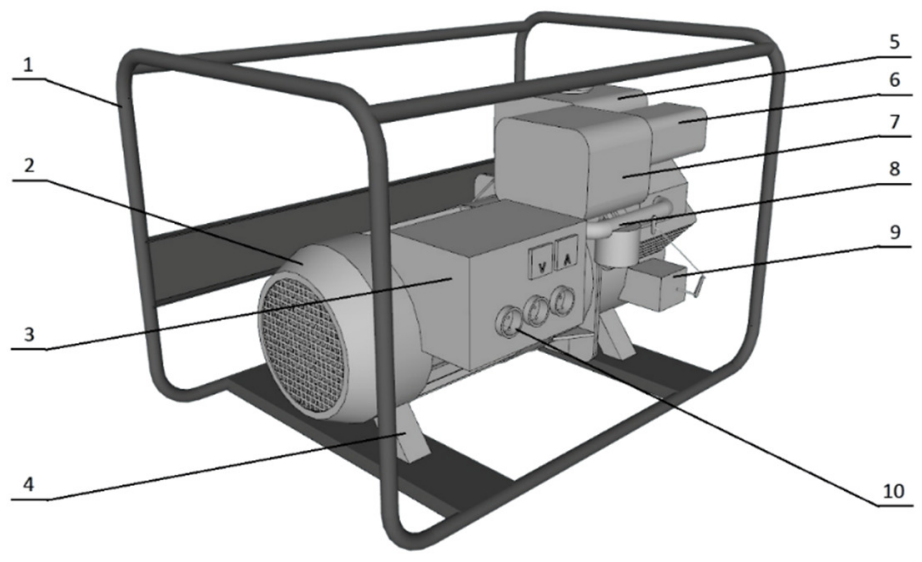

Rysunek 1. Widok ogólny agregatu prądotwórczego.

Agregat składa się z ramy nośnej (1), prądnicy (2), modułu (3) zawierającego zespół bezpieczników, woltomierz i amperomierz (opcjonalnie) oraz co najmniej jedno jednofazowe gniazdo do podłączenia odbiorników (10). Dzięki zwartej i modułowej budowie w większości agregatów prądotwórczych silnik spalinowy wyposażony jest 
we wszystkie niezbędne do pracy układy i nie wymaga żadnych przeróbek na potrzeby konwersji. Powyższe wyposażenie obejmuje: zbiornik paliwa wraz z przewodami i zaworem odcinającym (5), układ wydechowy wraz $\mathrm{z}$ tłumikiem wydechu (6), układ dolotowy wraz z filtrem powietrza (7), układ zasilania wraz z gaźnikiem (8) oraz układ stabilizacji prędkości obrotowej silnika niezależnie od obciążenia (9).

Rysunek 2 przedstawia projekt hamowni, zbudowanej w oparciu o elementy agregatu. W celu przekształcenia agregatu w hamownie silnikową należy w pierwszej kolejności zdemontować zespół prądnica-silnik spalinowy z oryginalnej ramy nośnej (1). Następnie konieczne jest przygotowanie sztywnej podstawy, do której zostaną zamontowane wszystkie elementy.

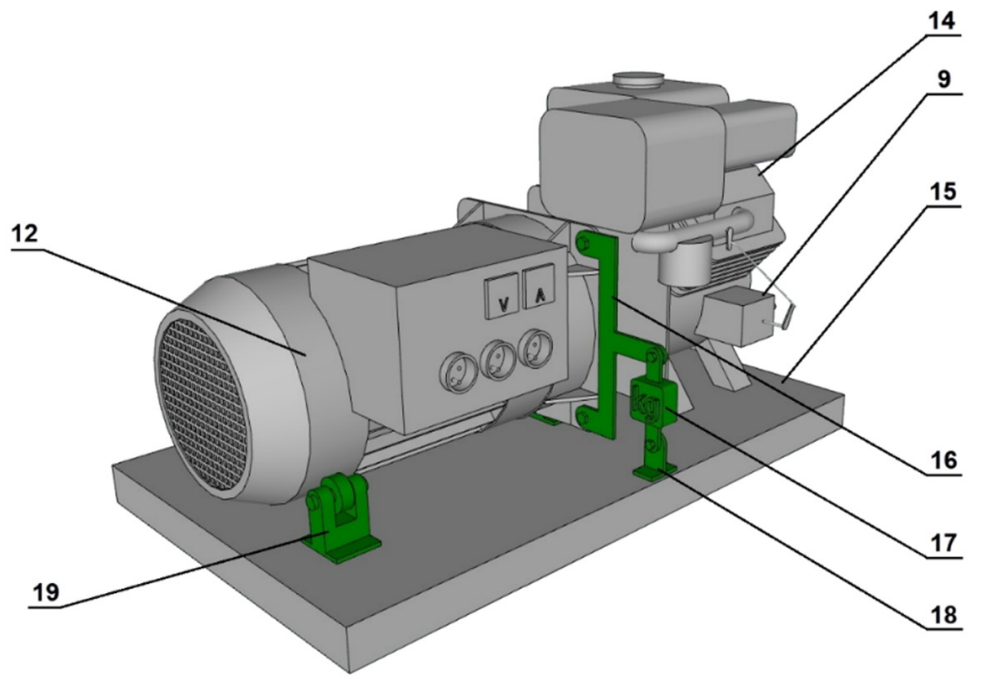

Rysunek 2 Zmontowana hamownia z elementami dodatkowymi

Typowo wykorzystuje się w tym celu płytę stalową (15) o wymiarach co najmniej takich jak wymiary zespołu prądnica-silnik. Silnik spalinowy i prądnicę rozdziela się mechanicznie tak, aby jedynym połączeniem między nimi był wał napędowy z przegubem elastycznym kompensującym naprężenia i błędy położenia wałów względem siebie (21) (rys. 5).

Zamocowanie silnika spalinowego pozostawia się bez zmian względem oryginalnego pod warunkiem, że gwarantuje ono stabilne jego mocowanie i tłumienie wibracji. W tym celu wykorzystuje się elementy elastyczne (4) przedstawione na rys. 2. Aby umożliwić pomiar momentu obrotowego generowanego przez silnik spalinowy prądnicę umieszcza się na specjalnym mocowaniu umożliwiającym jej obrót wokół własnej osi. Elementami tego mocowania są: dwa łożyska kulkowe z obudowami umożliwiającymi ich zamocowanie do podstawy (19) pokazane na rys. 3 oraz 4 oraz podpora z łożyskiem kulkowym (20), (rys. 5), podtrzymująca wał prądnicy. 


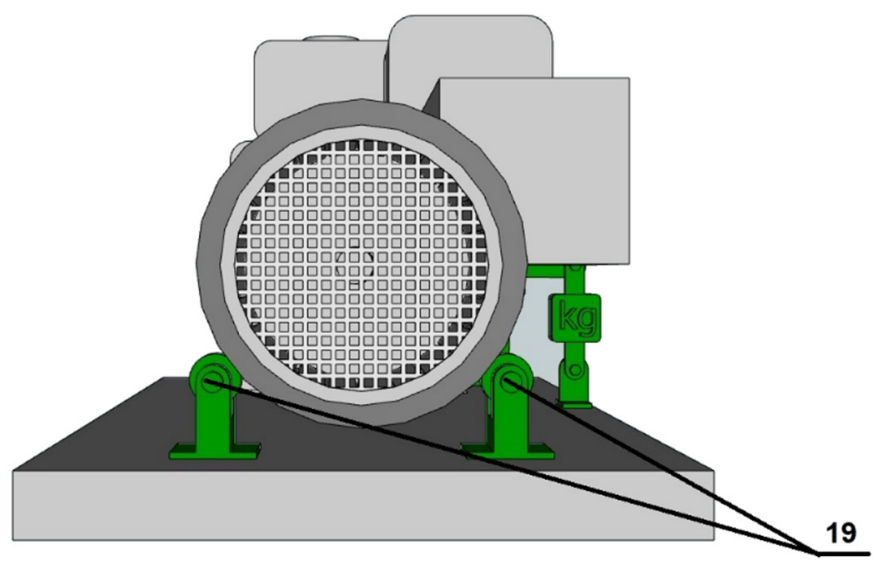

Rysunek 3. Widok na łożyska stabilizujące prądnice

W celu wykonania pomiaru momentu obrotowego prądnice wyposażono $\mathrm{w}$ ramię czujnika siły (16), wagę wyskalowaną w jednostkach siły z odczytem elektronicznym (17) oraz mocowanie wagi do płyty (18) pokazane na rys. 3

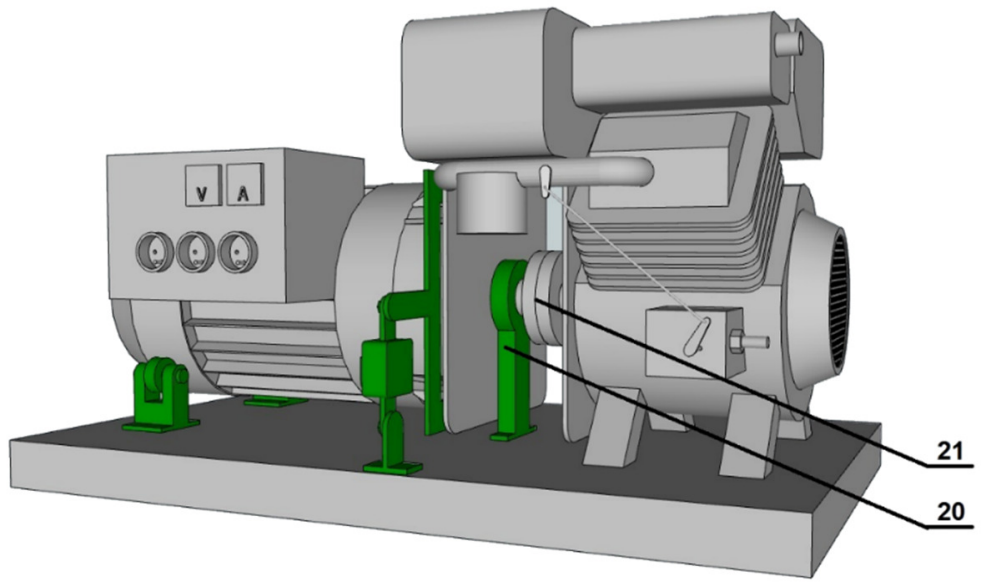

Rysunek 4. Widok na podporę watu napędowego

\section{Opis działania}

W celu wykonania pomiaru momentu obrotowego silnika spalinowego należy, po jego uruchomieniu, wyzerować wskazanie czujnika siły. Następnie podłączyć do gniazda (10) obciążenie o regulowanej mocy (np. grzejnik) nie przekraczającej mocy maksymalnej prądnicy (2) określonej w instrukcji agregatu. W kolejnym kroku za pomocą regulatora prędkości obrotowej ustawić żądaną wartość prędkości silnika wykorzystując dodatkowo obrotomierz. Następnie zwiększając moc na odbiorniku 
ustawić żądany punkt pracy silnika i po ustabilizowaniu parametrów z wyświetlacza czujnika siły odczytać siłę generowaną na ramieniu (16). Moment obrotowy silnika oblicza się korzystając z powyższego odczytu i znając odległość zamocowania czujnika siły od osi wału. W tym celu wykorzystuje się przedstawiony poniżej wzór:

$$
M_{o}=F_{k p} \cdot r
$$

gdzie:

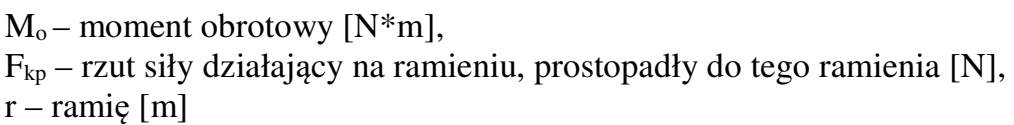

\section{Podsumowanie}

Przedstawiona powyżej hamownia nie jest urządzeniem pomiarowym. Ma jedynie na celu przybliżyć uczniom szkół technicznych bądź też studentom budowę i zasadę działania hamowni silnikowej silników spalinowych bądź elektrycznych.

Dnia 17.09.2021 zgłoszono w Urzędzie Patentowym RP wynalazek, obejmujący przedstawione rozwiązania.

Zgłoszenie wynalazku zawiera następujące zastrzeżenia patentowe:

1. Hamownia silnikowa do celów dydaktycznych znamienna tym, że do jej budowy wykorzystano agregat prądotwórczy dowolnego producenta wyposażony w: ramę nośną (1), prądnicę (2), moduł (3) zawierający zespół bezpieczników, woltomierz i amperomierz (opcjonalnie) oraz co najmniej jedno jednofazowe gniazdo do podłączenia odbiorników (10), zbiornik paliwa wraz z przewodami i zaworem odcinającym (5), układ wydechowy wraz z tłumikiem wydechu (6), układ dolotowy wraz z filtrem powietrza (7), układ zasilania wraz z gaźnikiem (8) oraz układ stabilizacji prędkości obrotowej silnika niezależnie od obciążenia (9).

2. Hamownia silnikowa wg. zastrzeżenia 1, znamienna tym, że silnik (14) i prądnicę (12) rozdzielono mechanicznie i połączono tylko wałem napędowym ze sprzęgłem elastycznym (21) i osadzono na sztywnej postawie.

3. Hamownia silnikowa wg. zastrzeżenia 1 , znamienna tym, że prądnica osadzona jest na dwóch łożyskach kulkowych z oprawami (19) zamocowanymi do sztywnej podstawy (15) oraz na podporze z łożyskiem (20) przez które przechodzi wał napędowy. Podpory te umożliwiają swobodny obrót prądnicy wokół osi wału.

4. Hamownia silnikowa wg. zastrzeżenia 1, znamienna tym, że odczyt wartości siły odbywa się na wyświetlaczu czujnika siły (17) zamontowanym na dodatkowym ramieniu (16), bądź też w programie komputera do którego podłączono czujnik siły (17) za pomocą wyjścia komunikacyjnego. 


$\begin{array}{ll}\text { URZAD PATENTOWY } & \text { al. Niepodleglości 188/192 } \\ \text { RZECZYPOSPOLITEJ POLSKIEJ } & 00-950 \text { Warszawa, skr. poczt. 203 } \\ \text { tel.: (+48) 22579 } 555 \text { | fax: (+48) 22 } 5790001 \\ \text { e-mail: kontakt@uprp. gov.pl | www.uprp.gov.pl }\end{array}$

Kancelaria Ogólna

Warszawa, 2021-09-17

Nasz znak: P.438972

Wasz znak: Brak

\section{POTWIERDZENIE}

Urząd Patentowy RP stwierdza, że dnia 2021-09-17 przyjęto w formie elektronicznej wniosek o udzielenie patentu na wynalazek:

Hamownia silnikowa do celów dydaktycznych

Zgłoszenie oznaczono numerem: P.438972

[WIPO ST 10/C PL438972]

Zgłaszający: Kamil Węglarz, Kozy, Polska

Marcin Sidzina, Brenna, Polska

Dokument wystawiony automatycznie przez system teleinformatyczny UPRP.

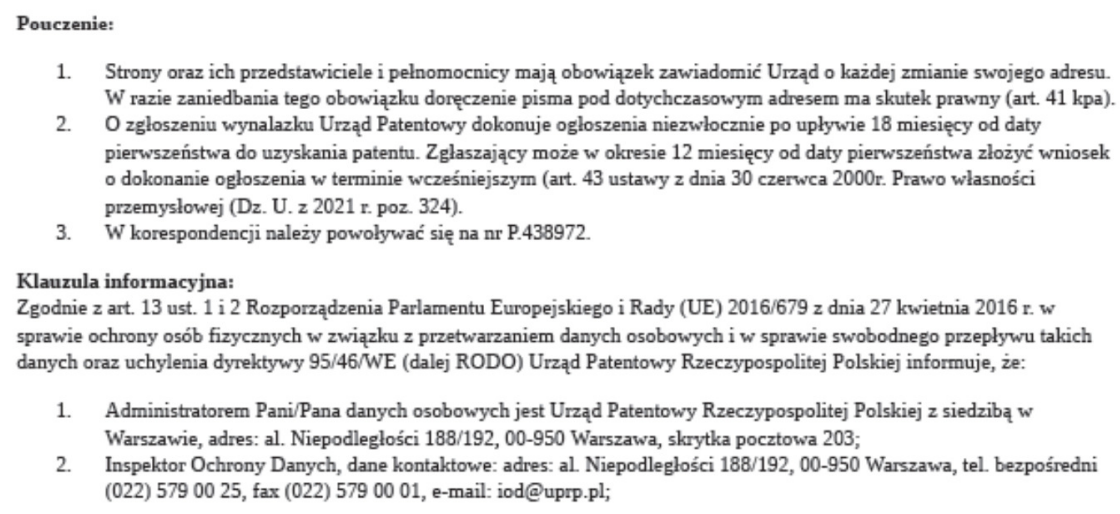

1. Strony oraz ich przedstawiciele i pelnomocnicy mają obowiązek zawiadomić Urząd o każdej zmianie swojego adresu. W razie zaniedbania tego obowiazku doreczenie pisma pod dotychczasowym adresem ma skutek prawny (art. $41 \mathrm{kpa}$ ).

2. O zgloszeniu wynalazku Urząd Patentowy dokonuje ogloszenia niezwlocznie po uplywie 18 miesięcy od daty pierwszeństwa do uzyskania patentu. Zglaszający może w okresie 12 miesięcy od daty pierwszeństwa złożyć wniosek o dokonanie ogloszenia w terminie wcześniejszym (art. 43 ustawy z dnia 30 czerwca 2000r. Prawo wlasności przemyslowej (Dz. U. z 2021 r. poz. 324).

3. W korespondencji należy powolywać się na nr P.438972.

Klauzula informacyjna:

Zgodnie z art. 13 ust. 1 i 2 Rozporządzenia Parlamentu Europejskiego i Rady (UE) 2016/679 z dnia 27 kwietnia 2016 r. w sprawie ochrony osób fizycznych w związku z przetwarzaniem danych osobowych i w sprawie swobodnego przeplywu takich danych oraz uchylenia dyrektywy 95/46/WE (dalej RODO) Urząd Patentowy Rzeczypospolitej Polskiej informuje, ż:

1. Administratorem Pani/Pana danych osobowych jest Urząd Patentowy Rzeczypospolitej Polskiej z siedzibą w Warszawie, adres: al. Niepodległości 188/192, 00-950 Warszawa, skrytka pocztowa 203;

2. Inspektor Ochrony Danych, dane kontaktowe: adres: al. Niepodleglości 188/192, 00-950 Warszawa, tel. bezpośredni (022) 5790025 , fax (022) 57900 01, e-mail: iod@uprp.pl;

\section{Rysunek 5. Potwierdzenie złożenia w Urzędzie Patentowym RP wynalazku}

Teoretyczna analiza i projekt wykazuje użyteczność przedstawionego rozwiązania pod kątem wykorzystania do celów dydaktycznych. Kolejnym etapem będzie przygotowanie prototypu, który pozwoli na rozwinięcie i analizę przedstawionych rozwiązań. Prototyp pozwoli na weryfikację funkcjonalności i trwałości elementów i wprowadzenie niezbędnych poprawek gwarantujących zadowalający poziom jakości. 


\section{LITERATURA}

1. Honda ECT7000P Technical Datasheet, 2018 r.

2. Strona internetowa www. https://global.honda/

3. KURANC A.: Badania mocy silnika pojazdu $\mathrm{z}$ wykorzystaniem metod inercyjnych, Autobusy, 2018.

4. LANZENDOERFER J.: Badania pojazdów samochodowych. WKiŁ, Warszawa 1977.

5. BOSCH: Czujniki w pojazdach samochodowych, WKiŁ, Warszawa 2014. 